\title{
大規模卸売企業の戦略的行動に基づく 流通短縮化の考察
}

\author{
金雲 鎬 \\ (神戸大学)
}

\section{要約 (アブストラクト)}

本稿は、日本の流通短縮化現象の規定要因を、技術発達による流通サービス費用の減少によるものとして捉 えた既存研究とは異なり、その技術発達が流通機関の戦略行動に影響をあたえ、その戦略行動の結果として流 通短縮化が進むことを主張する。特に、流通機関の中でも集中度の変化が顕著に生じる卸売業界の動きに注目 し、大規模卸売企業の戦略的行動が小売企業との関係を変化させる局面に焦点を当てている。そのために、大 規模卸売企業の物流高度化と小売企業に対する販売先絞込みといった戦略的行動に注目し、卸売企業に対する 調査から卸売企業の戦略的行動と流通短縮化との関係を検討する。この分析の結果、物流高度化を実行する卸 売企業の小売企業に対する販売先絞込みが卸売段階の集中度を変化させ、それの変化が流通短縮化をもたらす 点が明らかになる。

キーワード

流通短縮化、卸売企業戦略、取引依存度、卸売段階の集中度

\section{I . 問題意識}

流通構造を把握し、その変化を分析する方 法として、W/R比率のように流通における段 階数に注目する見解と、集中度という大規模

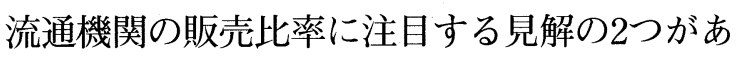
る(田島義博 ·宮下正房1985、田村1986)。平 成13年度の商業統計では、W/R比率が1982年 の4.24から1999年の3.45へ減少していることが 示されている。流通構造が「流通システムの各 要素のあいだの諸関連が全体としておりなす パターン」(田村,1984)であることを考慮すれ ば、これは現在の流通システムが流通短縮化 に向かって動いていることを意味する。この 変化は、長年の間、日本の流通構造の特徴と 言われてきた流通構造の多段階性に変化が起
こっていることを示唆するものである。

それでは日本の流通短縮化をもたらしてい る要因として、何が考えられるだろうか。 その要因として今までは(1)技術発達による流 通サービス費用構造の変化と (2) メーカーと小 売企業による中間業者の排除といった局面で の分析が多く展開されてきた。

前者に関して、商業統計では、この要因と して、流通段階での積極的な技術導入を挙げ ている。その考えは、Bucklin(1966)の流通 サービス費用と流通段階の関係から説明でき る。また高嶋(2002)では、技術発達によって 流通サービス費用構造が大きく変わることを 分析している。そして後者に関しては、メー カーのチャネル政策の転換及び製版統合と 
いった局面で説明することが主流であった。

このような考えは、技術の発達とメーカー および小売企業の戦略的行動が、日本の流通 構造を複雑にした卸売段階を単純化すること により全体として流通短縮化が行われるとい う観点に立っている分析である。

しかしながら、最近の卸売業界では、卸売 企業の大規模化、総合化、広域化、さらには 大規模卸売企業による中小卸売企業への合併 が展開されている (矢作1996、小西2000、高嶋 2002、金2003)。また対小売戦略として情報シ ステムの導入、物流の高度化、リテールサ ポートの高度化抢よびPB開発などの諸戦略が 必要であることが指摘されている(宮下1996、 矢作1996、日経流通新聞2001、渡辺2002、高 嶋2002、中西・杉本2002)。卸売業界で見られ るこのような現象は従来には見られなかった 新しいものであり、このような現象の分析は 現代の流通システムを理解するうえで非常に 重要な研究課題でもある。

こうした現象を流通構造と関連して考えてみ ると卸売企業の戦略行動と流通構造との間に は深い関係があることが考えられる。つま り、卸売企業の物流高度化といった行動は販 売先への集中を引き起こすことになり、これ によって仕入れ側(小売業界) と販売側(卸売業 界)には取引集中が行われることになる。また 卸売業界の同盟化、卸売企業の大規模化は大 規模卸売企業と大規模小売企業との取引集中 によるその業界内部の集中度が変化すること を意味し、この小売・卸売業界の集中度の変 化はまさに流通構造の変化(ここでは流通短縮 化)を意味するに違いない。したがって、流通 短縮化の規定要因として今まで言われた諸要 因以外にも、卸売企業の物流高度化といった 戦略行動に注目する必要があるのである。し かし、従来の議論の多くはここを看過してい る。そこで本稿では、このような問題意識か
ら、まず流通短縮化に関する先行研究のレ ビューを行うことにする。

\section{1. 流通短縮化の規定要因に関する先行研究の レビュー}

流通短縮化のメカニズムを説明する既存研 究は、「技術発達を流通短縮化の主要要因とす る研究」と「日本の流通特性に注目しながら流 通短縮化の規定要因を探る研究」の二つに分け ることができる。前者は、流通構造の多段階 化を規定する要因を分析し、その多段階化の 規定因の変化を考察することで流通短縮化が 行われるメカニズムを解明する見解である。 そして後者は、主要流通機関の戦略的行動が 流通構造に与える影響に注目し、主要流通機 関の戦略的行動を流通短縮化の主要因とする 見解に立っている1。

\section{1 - 1. 技術発達を流通短縮化の主要要因とす る研究}

丸山(1992)は取引のネットワーク分析を通 じて、卸売短縮化の可能性を論じている。こ の取引のネットワーク分析は、卸売企業の介 在により取引総数が減少するというHall(1948) の理論に基づいたものである。すなわち、卸 売企業の取引管理能力に限界があれば、たと え多数の小売企業が存在しても、すべての需 要を集計化することは不可能になるので、流 通は多段階化することになる。しかし、この ような卸売企業の取引管理能力の限界は、情 報技術の発達や卸売段階の組織化が行われる ことにより、克服することができるのであ る。そして、それによって流通短縮化が起こ りうるのである。このような考えは、次のよ うな丸山(1992)から読み取ることができる。

「卸売の多段階性は、個々の卸売企業の取引の管 理能力の限界から派生するとすれば、日本に打い て最近進みつつある情報技術発達の流通分野への 
浸透や卸売段階の組織化が、取引の管理能力を高 め、流通経路構造の変化につながるものと考えら れよう。」(丸山1992,p.67)

また、高嶋(2002)では、Bucklin(1966)に基 づき商品流通の流通サービス量が、流通サー ビスの分業化をもたらすことによって、流通 の多段階化が進行すると論じている。この考 え方では、流通構造が多段階になる要因とし て、商品流通サービス量の増加を問題として いる。そして、メーカーや流通機関が物流情 報システムを導入すると、費用曲線のシフト が発生し、品揃えの懸隔を埋めるための作業 が効率的に行われるために、多段階の卸売企 業で分業する必要性が少なくなると考えるの である。

\section{1 - 2. 流通段階ごとの戦略的行動に注目して 流通短縮化の主要要因を探る研究}

このタイプの研究は、メーカーによる流通 機関の垂直統合や大規模小売企業による後方 統合などのように、メーカーや流通機関の戦 略的行動が流通構造を変化させる点に着目 し、流通短縮化のメカニズムを説明してい る。さらに、この視点の研究は, 以下のよう に、メーカー主導による流通短縮化を強調す る研究と小売企業主導による流通短縮化に分 けることができる。

\section{メーカー主導による流通短縮化}

流通短縮化に関する理論研究の中には、 メーカーの垂直統合による取引の内部化が、 流通の段階構造の短縮化を引き起こしている と説明するものがある(田村1986、鳥居1987、 丸山1988、成生1994)。丸山(1988)は、垂直的 統合が流通短縮化につながる可能性を次のよ うに述べている。

「流通系列化が、資本的・人的交流関係を伴う垂 直的統合という形態をとれば、流通段階の短絡化
となるが、それが市場的取引と組織内取引の中間 領域に位置する中間組織的取引様式のように、必 ず資本的交流関係を持たない形で行われる場合に は、流通段階の短絡化としては認識されないこと になる。」(丸山 $1988, p .206$ )

このように、日本の流通系列化が、資本 的・人的交流関係を伴う垂直的な統合という 形態よりも、メーカーに内部組織化された中 間組織的な性格が強いということを考慮する と、日本の流通系列化が、そのまま流通の短 縮化につながっているとは言いがたい。しか し、田村 (1986)のマクロデータ分析では、 メーカーによる内部組織化と流通経路構造の 変化には深い関連があることが確認されてい る。すなわち、他の産業と比べて、食料・飲 料、医薬品 ·化粧品、機械器具、化学製品、 鉱物・金属材料の分野では、第二次卸売取扱 高の構成比が少なく、そのために流通経路が 短いということが言えるのである。また、成 生(1994)では、業種別マージン率による分析 から、自動車・家具などの耐久消費財の場合 は、アメリカよりもむしろ日本で流通経路が 短くなっていることが確認されている。

したがってこれらの見解には多少の相違が

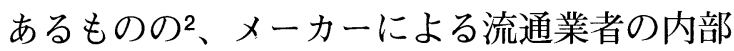
組織化が、流通短縮化につながる可能性があ ることを示唆していると読み取ることができ る。

\section{小売企業主導による流通短縮化}

この視点での研究としては、メーカーと小 売企業との直接取引によって卸売段階が排除 される可能性に注目した中抜き論とメーカー のチャネル政策の変化による卸売段階の存立 基盤の沈下に関する議論が挙げられる。 中抜き論は、林(1962)や田島 (1962)によって 主唱された、いわゆる問屋無用論である。大 規模小売企業が取引上の効率性を求めて、 
メーカーとの直接取引に乗り出すことによ り、その中間段階に位置している卸売企業の 存立根拠が危うくなるという理論である。問 屋無用論が登場してから、最近まで卸売段階 の排除が顕著になっていないことから、問屋 無用論を否定する声もあったが、近年では、 チェーン・オペレーションを展開する大規模 小売企業を中心として、卸売企業を選別する 行動が見られるようになっている。このよう な卸売企業との協調的な関係が強調されなが らも、能力のない卸売企業を排除する側面が あるという理論を、第二次流通革命論(新問屋 無用論)と呼ぶこともある(上原, 1993)。

一方、これとは違った見解から卸売段階の 短縮化の可能性を論じている研究がある。高 嶋 (1994) は、大規模小売企業の購買支配力が メーカーのチャネル政策の変化を促すこと で、卸売段階が縮約されることを説明してい る。ここでは, 取引環境の変化に対してメー カーが、大規模小売企業との取引を拡大する ために、またその取引拡大時のパワー関係を 調整するために(購買支配力に対抗するため に)、取引関係にある卸売企業を統合し、規模 を拡大させて再配置する必要があるというこ とが説明されるのである。

\section{2. 流通短縮化研究に関する問題提起}

以上の流通短縮化の規定要因に関する既存 研究から、技術発達の側面において情報シス テムの導入が、また、流通機関の行動要因の 側面ではメーカーと小売企業の戦略行動の変 化が流通短縮化をもたらす主要因として強調 されてきたことが分かる。

しかし、このような流通短縮化に関する既 存研究の検討から二つの疑問が生じる。ま ず、流通短縮化に影響を与えると思われる技 術発達とメーカーと流通機関の戦略行動との 間の関連性に関する疑問がある。技術発達が
あっても技術を導入するにはコストやリスク を伴うために、企業においては，投資に関わ る戦略的意思決定が行われることになる。そ れが技術発達と流通短縮化には因果関係が想 定されるものの、メーカーと流通機関の戦略 的行動によって媒介される点に注意する必要 がある。

\section{図1. 流通機関の戦略的行動と流通構造との関係}

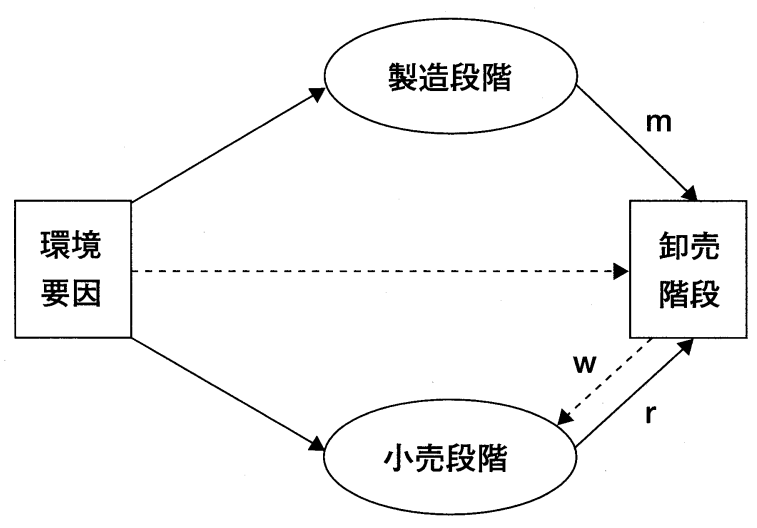

出所. 筆者作成

さらに言えば、既存研究ではメーカーと小 売企業の戦略的行動による流通構造変化の可 能性が注目されているが(図1の経路mとr)、 もう一つの流通機関である卸売企業の戦略的 行動による影響も考える必要があるだろう。 卸売企業が流通を支配していた時代の後、 卸売企業主導のもとで流通革新の現象がほと んどなかったことは事実である。ところが、 現在の卸売業界を見ると、卸売企業の中に は、この厳しい環境を逆に機会として捉えて 積極的に対応することで、高い収益率をあげ たり企業規模を拡大したりする企業が多く見 られるのである (小林 1994 、佐藤・高宮城 1995、矢作1996、渡辺1997・2002)。そ机らの 卸売企業に見られる共通の特徴として、規模 が大きいことと物流高度化を積極的に導入し ていること、そして販売地域を拡大したり、 品揃えの品目を増やしたりするなどの戦略を 
自立的に展開していること、の3つを挙げるこ とができる。これらの諸特徴は、卸売段階の 集中度を変化させることになり、その結果、 流通短縮化といった流通構造を变化させるこ とになる可能性が高いと思われる。しかし、 この卸売企業の主導による流通構造の変化と いう側面について、既存研究では説明されて いないのが現状である。

この問題を考えるために、本稿では技術導 入に打ける卸売企業の戦略的行動が流通短縮 化に与える影響について検討することにす る。具体的には、技術発達が卸売企業の行動 にどのように影響を与えるのか、またその卸 売企業の行動が流通短縮化にどのように影響 を与えるのか、といった局面での考察が必要 になる。よって、大規模卸売企業の戦略行動 による流通短縮化の分析という試みは、流通 構造の変化の規定要因に対する新しい分析視 角を提供するものと考えられる3。

\section{II. 仮説の導出}

まず図1において、経路 $\mathrm{w}$ のように卸売企業 と小売企業との間の関係から流通構造の変化 を議論するためには、卸売段階の企業行動の なかでも大規模卸売企業の物流高度化といっ た戦略的な行動に注目する必要がある。それ は、物流高度化による卸売企業の物流処理能 力の向上が小売企業との間で取引依存関係に 影響を与えることを通じて流通構造に影響す ると予想されるためである4。

そこで、本節では大規模卸売企業が物流高 度化を実行する際にどのような戦略的行動が 行われるかを検討し、その後、それによる戦 略的行動が流通構造にどのような影響を与え るかを考察することにしたい。

\section{1. 戦略的行動としての大規模卸売企業の物流 高度化}

卸売企業の物流高度化では大規模な投資が 必要になるために、中小卸売企業よりも投資 能力を持っている大規模卸売企業の方が採用 しやすいと考えられる。さらに、大規模卸売 企業を中心に物流高度化が採用される背景に は、大規模小売企業を中心とした小売企業側 の論理がある。それは、利用可能な資源をで きるだけ多店舗展開のために集中しながらも 消費者需要の多様化といった環境の変化に効 率的に対処することが小売企業にとって経営 のうえで最も重要になっているためである。 消費者需要の多様化といった状況では、消費 者の需要の動向を的確に把握し、速やかに対 応して仕入れることが大事になる。それは、 顧客の確保のためでもあるが、また、売れ残 り在庫の減少といった在庫の問題の解決のた めにも不可欠なものである。さらに、チェー ン展開する大規模小売企業を中心に、小売企 業は多店舗戦略を主要戦略として採用してい るために、資源の効率的な配分が重要にな る。この局面で小売企業が取り得る行動とし ては、高度の物流処理能力を持っている第三 者に物流部門を外部化することが考えられ る。すなわち、物流部門への投資を供給業者 や専門物流業者などへ委ねることで多店舗展 開に使用可能な資源を集中することができる ようになるのである(Maltz1993,渡辺1997)。

このような小売企業側の物流における戦略 は、卸売企業にとっては重要な取引チャンス になるのである。すなわち、小売企業が物流 に求めている条件を満たすことによって大規 模小売企業との戦略的パートナーシップを築 くことが可能になる。また、その関係から低 い物流処理コストを達成したり、安定的な販 売先を確保したりすることができるようにな るのである。ここに、卸売企業が大規模投資 
を伴っても物流高度化を実行する背景があ る。

卸売企業が物流高度化をはかる場合、投資 リスク、大規模小売企業との依存関係の深化 などの、多様なリスクが予想できることか ら、物流高度化の実行はそれだけで戦略的な 行動といえるだろう。しかし、長年、卸売企 業がメーカー依存型の取引行動を見せてきた ことから、その戦略行動が小売側の要求によ る受動的な対応と見る視角もありえる。そこ で、卸売企業の物流高度化の自立性を確認す るために、物流高度化を説明変数と処理し、 小売側またはメーカー側の要求、そして経営 の合理化などを被説明変数と処理した統計分 析を行った。その結果から小売側の要求より は、経営合理化や情報システムの活用など、 より自立的な要因によるものであることが分 かる5。

\section{2. 大規模卸売企業の戦略的行動と流通短縮化 との関係}

それではこのような大規模卸売企業の物流 高度化が、流通短縮化にどのように関連して いるのか、以下ではこの点を中心に議論した い。

\section{大規模卸売企業の物流高度化と取引集中}

卸売企業が物流高度化を実行する場合、そ の高度化された物流システムを効率よく活用 するためには、大規模な取引が必要であり、 大量の注文が期待できる大規模小売企業を販 売先として選ぶ可能性が高い。ただ、大規模 な取引ができる小売企業はそれほど多くない ため、特定の大規模な小売企業に限定されて しまう。すなわち、販売先が大規模小売企業 に絞り込まれるのである6。したがって、販売 先の絞込が進展すればするほど、卸売企業に とっての主要小売企業への販売依存度は高く
なってしまうのである。

次に多店舗展開戦略を主要戦略とする大規 模小売企業に目を向けてみる。前述したよう に、物流部門を供給業者に依存したほうが効 率的になるため、物流高度化を実行している 卸売企業を利用する必要があると考えられ る。特に、在庫問題をより効果的に解決する ためには、小売企業は多数の卸売企業と取引 するよりも少数の卸売企業に集約するほう が、発注や荷受などの作業が簡単に済むの で、コストが削減しやすい。よって、大規模 小売企業は、卸売企業に対する絞込みを行う ことになり(上原1993、高嶋2002)、卸売企業 に対する小売企業の仕入れ依存度は高くなる と考えられる。

このように、大規模卸売企業を中心に物流 高度化が実行されると、主要小売企業との取 引関係において、小売側の仕入れ依存度と卸 売側の販売依存度がともに引き上げられ、卸 売と小売業界における二極化をもたらすひと つの要因になると考えられる。つまり、この 二極化の進展は、集中度の変化を意味するも のとして考えることができるのである。

\section{取引集中と流通短縮化}

大規模卸売企業を中心に採用される物流高 度化によって、卸売、小売業界に取引集中が 発生することが考察された。では、この取引 の集中が流通構造の中でもつ意味は何なのだ ろうか。

一言で言うと、多段階な流通システムの短 絡化、つまり、流通短縮化である。流通の多 段階性は卸売段階の複雑性に起因するもので ある(田村1986)ことから、卸売段階の集中度 の変化を中心に記述すると、流通短縮化は2つ の局面から発生すると考えられる。

第一は、中小卸売企業の主要販売先の衰退 
である。前項でも説明したように卸売業界と 小売業界において二極化が進展するため、大 規模卸売企業の物流高度化を媒介として、大 規模の卸売企業と大規模小売企業との間の取 引の引き上げが生じると考えられる。そのた めに、残された中小小売企業は排除される可 能性が高い。こうした取引からの排除は、中 小小売業の経営基盤の縮小をもたらし、立場 を弱いものにしてしまう。さらに、中小卸売 企業の主要販売先は中小小売企業であること が多く、中小小売企業の衰退は、中小卸売企 業の主要販売先の衰退を意味しているので る。この主要販売先の衰退によって、姿を消 す中小卸売企業が発生するので、その分だけ 全体の卸売企業の数は減り、流通短縮化が進 むのである。

第二は、所有権移転の観点である。上記の 理由から厳しい経営環境に強いられた中小卸 売企業は、広域展開を困る大規模卸売企業に よって吸収される可能性が高く、この状況で は中小卸売企業は大規模卸売企業の支店とし て機能することになる8。この関係における本 支店間移動は、企業内取引であるから、所有 権移動が発生しない。流通における段階数あ るいは流通経路の長さは、所有権移転の回数 によって図られると見ることができるため(田 村1986)、本支店間移動の増加は卸売段回数を 減少させる要因として働くことになる。この 本支店移動の増加を引き起こしている最大の 要因は、広域化した卸売企業の本店から支店 への移動であり、これは卸売企業による卸売 段階の垂直統合を意味している。よって、こ の局面でも流通短縮化が進むことになるので ある。

以上のことから、二極化の進展は、卸売段 階に打いて大規模卸売企業の販売比率を上昇
させるとともに、卸売段階の集中度に変化を もたらし、それによって流通短縮化を招くと 考えられる。すなわち、物流高度化を実行す る卸売企業の場合は、物流高度化を実行しな い卸売企業に比べ、大規模小売企業に対する 販売依存度の上昇に伴う規模の増加幅が大き いと予想される。以上の関係から、卸売企業 の物流高度化という戦略的行動が流通短縮化 の規定要因になることが言え、次のような仮 説が導出される。

仮説：物流高度化を実行する卸売企業の場 合、大規模小売企業への販売依存度と 卸売企業規模との間に正の関係があ る。

\section{III . 研究方法と分析結果}

\section{1. 研究方法}

\section{調查方法(経験的調查の実施要綱)}

仮説のように卸売企業の小売企業に対する 戦略的行動と流通短縮化との関係を究明する ために、卸売企業を対象としたアンケート調 査を 2004 年 2 月に実施した (全体発送数 4000 社)。その結果、500社から回答があり(回収率 $12 \%$ )、有効回答数は 479 社であった9。

\section{測定尺度 (变数の設定) および検証方法}

本稿の目的は、大規模卸売企業の戦略的行 動によって卸売段階の集中度の変化が起こ り、流通短縮化が進む局面を説明することに ある。特に、卸売段階の集中度の変化を測定 することに扔いては、卸売企業の大規模化が 構造変数になりうると考えられるので、卸売 企業の従業員数を従属变数として採用した。 そしてその卸売企業の大規模化には、小売企 
業との取引依存関係が影響を与えていると予 想される。具体的には、特定小売企業への販 売依存度の増加が、卸売企業の小売企業に対 する販売先絞込みを促進させ、その関係のも とで卸売企業の大規模化が進む、というもの である。そのため、大規模小売企業に対する 卸売企業の販売依存度を一つの要因として検 討する。大規模小売企業としては、百貨店、 全国スーパーチェーン、コンビニエンススト ア、量販専門店・ディスカウントストア、そ して生協や農業への売上を合計した值を利用 した。

さらに、このような関係は卸売企業の物流 高度化の実行有無によって大きな影響を受け ると考えられるために卸売企業の物流高度化 を意味する「直接投資をし、新しい物流セン ターを建設」と、「既存の物流センターへ情報

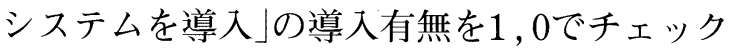
し、それを得点化したものを物流高度化変数 として定め、0を0に、1から4を1とするダミー 変数として捉えることにした ${ }^{10}$ 。

仮説の検証のためにここでは、5点尺度で測 定したデータを間隔尺度データとして捉えて いる。仮説の検証の際には、卸売企業の企業 規模を従属変数とし、大規模小売企業への販 売比率(低／高、50\%によって2分割) と卸売企 業の物流高度化実行有無という2つの要因を因 子とする 2 元配置分散分析を実施し、仮説の検 証を行った。

\section{2. 分析結果}

\section{仮説の検証}

卸売企業の企業規模を従属変数にして、大 規模小売企業への販売比率と物流高度化の有 無を因子とした2元配置分散分析を行ったとこ ろ、次のような結果が得られた。
表1. 従属変数一従業員数

\begin{tabular}{l|rrrr}
\hline ソース & 自由度 & 平均平方 & F値 & 有意確率 \\
\hline 修正モデル & 3 & 940345.671 & 6.187 & 0.001 \\
切片 & 1 & 4029179.1 & 26.509 & 0 \\
大規模小売への販売比率 & 1 & 524324.0456 & 3.5 & 0.065 \\
物流高度化 & 1 & 1299404.3 & 8.549 & 0.004 \\
大規模小売*物流高度化 & 1 & 452671.153 & 2.978 & 0.087 \\
誤差 & 134 & 151990.942 & & \\
総和 & 138 & & & \\
修正総和 & 137 & & &
\end{tabular}

\section{図2. 従業員数の推定周辺平均}

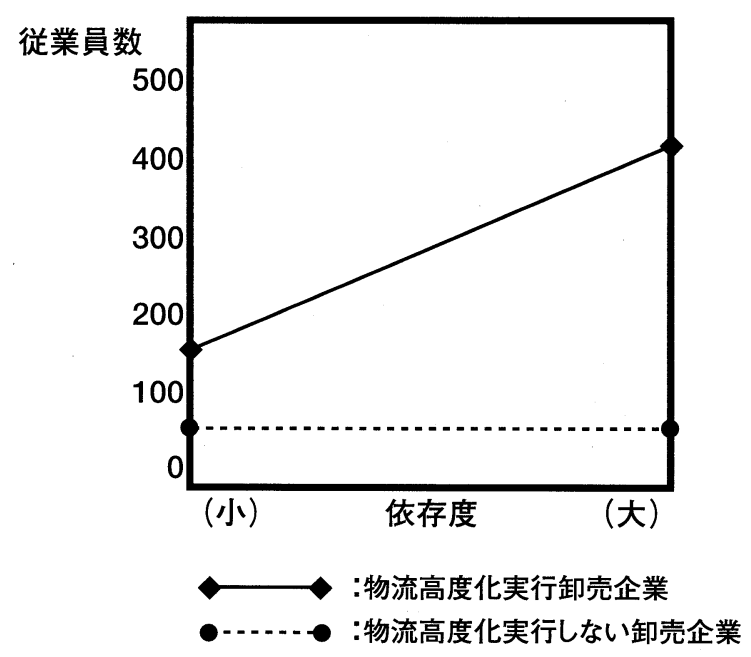

上記の結果から、卸売企業の大規模化に関 しては、卸売企業の物流高度化と大規模小売 企業への販売比率において有意な主効果が確 認された。そして大規模小売企業への販売比 率と卸売企業の物流高度化との間に有意な交 互効果が確認された。仮説の検証に関して は、有意な交互効果が確認されたため、やや 不安ではありながら仮説は支持されたと考え ることができる。

\section{結果の解釈}

大規模卸売企業を中心に物流高度化が採用 されると、その効率的な運用の必要性から販 売先の絞込みが行われる。この小売企業に対 する選別は、卸売段階における取引集中が一 層促進されることになり、その結果として、 流通短縮化が発生する。 
これらを実証するために、大規模小売企業 への販売比率と物流高度化を因子として、2元 配置分散分析を行った。その結果、卸売企業 の大規模化に関しては、物流高度化に打い て、有意な主効果が確認され $(\mathrm{p}<0.01)$ 、ま た大規模小売企業への販売比率因子でも主効 果が確認された $(\mathrm{p}<0.10)$ 。このような結果 は、卸売企業の物流高度化扣よび大規模小売 企業への販売比率と卸売企業の大規模化には 関係があることを読み取ることができる。さ らに、因子間に扎てても有意な交互効果 $(\mathrm{p}<$ 0.10)が確認されたことについては、物流高度 化を実行する卸売企業ほど大規模小売企業へ の販売が全体の販売に占める割合が高くなっ ていることを意味するが、それは物流高度化 を実行する卸売企業を中心に小売企業との取 引が集中することを意味する。すなわち、物 流高度化を実行する大規模卸売企業は、販売 先として大規模小売企業との取引強化を戦略 的に採用することが考えられる。卸売企業の 大規模化による取引集中が流通短縮化を説明 する構造変数であれば、以上の検証結果か ら、物流高度化を実行する大規模卸売企業の 販売先に対する戦略的行動(販売先として大規 模小売企業への集中)が流通短縮化の一つの規 定要因になるとみなすことができる。

\section{IV . 考察}

\section{1. ディスカッション}

本稿によってもたらされた理論的含意は、 以下の 2 点に集約される。第一は、流通短縮化 の規定要因における技術発達について流通機 関の戦略行動と関連して、経験データを用い てより詳細に検討した。特に、本稿のレ ビュー段階で検討した技術の発達による流通 短縮化の進展と流通機関の戦略的行動による
流通短縮化といった、流通短縮化と関連する 二つの理論間に存在する理論的間隔を埋める ような視点を提示した点にある。第二は、卸 売企業の戦略的行動に注目した研究の中で、 個別卸売企業をその卸売研究における研究単 位とした点である。従来の卸売研究では、個 別卸売企業の異質性や行動よりは卸売全体の 機能や存在意義などに注目していたために、 卸売研究における実務的な貢献がそしかった （黄1997）。そのことを考えれば、個別卸売企 業の行動に注目することは意義があると考え られる。

\section{2. 今後の課題}

しかしながら本稿は、いくつかの限界も有 している。まず、外的妥当性に関しては若 干の不安が残る。本研究で実施された調査は 日本の卸売業界に打ける調查であったが、そ の回収率は期待に反する低いものであった。 この点から、発見事項の一般化には慎重を期 するべきである。また上では、個別卸売企業 の異質性や行動に注目することから卸売企業 に対する実務的な貢献が生まれると論じた が、本稿はその可能性を示しているに過ぎな い。本稿では卸売企業の物流高度化と小売企 業に対する選別といった卸売企業の戦略的行 動に注目した。それに加えて、戦略的行動に よる結果の差としての企業成果を、卸売企業 の戦略展開と照らし合わせながら検討するこ とで、より実務的貢献が増すと思われる。こ の点については、今後の課題である。

また、流通短縮化の規定要因に関する他の 規定因を探ることが必要になる。ここで取り 上げた戦略的行動としては物流の高度化を中 心に議論を行った。この物流高度化に関し て、小売企業との取引関係の側面から考察し たが、それはまた他の側面による流通多段階 
性の変化をもたらす可能性がある。それは、 物流高度化が持っている属性によるもので、 お扰よそストダウンという局面から考えら れる。

卸売企業が物流高度化を実行することにな ると、まず、初期投資コストと特定小売企業 との取引拡大による依存関係の問題が発生す る可能性が高い。この問題を解決するために はさらなるコストダウン戦略および依存関係 の回復のための戦略が必要になると思われ る。取扱う品目を多様化することで一回配送 の効率を上げる総合化、そしてPB開発などが
その例として考えられる。これらの戦略を効 率的に展開するためには、中小卸売企業を統 合することが必要になり、流通の多段階性を 減少させる方向に働くと予想されるが、この 点に関してもさらなる研究が必要と思われ る。

以上のような限界はあるものの、大規模卸 売企業の戦略行動が流通短縮の規定要因の一 つであることを明らかにした点は、本稿の重 要な理論的な貢献であると考えられる。

参考1. 卸売企業の物流高度化の自立性 11

\begin{tabular}{|c|c|c|c|c|c|c|c|c|c|c|c|c|c|c|c|}
\hline & \multicolumn{3}{|c|}{ 被説明変数 (1) } & \multicolumn{3}{|c|}{ 被説明変数(2) } & \multicolumn{3}{|c|}{ 被説明変数 (3) } & \multicolumn{3}{|c|}{ 被説明変数(4) } & \multicolumn{3}{|c|}{ 被説明変数(5) } \\
\hline & $\beta$ & $\mathrm{t}$ & 有 & $\beta$ & $\mathrm{t}$ & 有 & $\beta$ & $\mathrm{t}$ & 有 & $\beta$ & $\mathrm{t}$ & 有 & $\beta$ & $\mathrm{t}$ & 有 \\
\hline 説明変数 & & & & & & & & & & & & & & & \\
\hline (1)販売先からの要求 & .104 & 1.474 & .141 & .077 & 1.136 & .257 & .090 & 1.233 & .219 & .081 & 1.103 & .271 & .105 & 1.550 & .122 \\
\hline (2)仕入先からの要求 & -.004 & -.057 & .954 & -.022 & -.360 & .719 & .039 & .596 & .551 & .061 & .933 & .352 & -.048 & -.788 & .431 \\
\hline (3)経営効率化のため & .050 & .571 & .569 & .189 & 2.251 & .025 & .012 & .127 & .899 & .013 & .141 & .888 & .164 & 1.970 & .050 \\
\hline (4)競争優位確保のため & .166 & 1.684 & \begin{tabular}{|l|}
.093 \\
\end{tabular} & .018 & .190 & .849 & -.013 & -.131 & .896 & -.033 & -.318 & .750 & .210 & 2.201 & \begin{tabular}{|l|l}
.028 \\
\end{tabular} \\
\hline (5)情報化効率向上ため & .043 & .525 & .600 & .171 & 2.143 & .033 & .052 & .599 & .549 & .124 & 1.416 & .158 & -.099 & -1.253 & .211 \\
\hline \multicolumn{16}{|l|}{ 説明率 } \\
\hline $\mathrm{R}$ & \multicolumn{3}{|c|}{.312} & \multicolumn{3}{|c|}{.382} & \multicolumn{3}{|c|}{.146} & \multicolumn{3}{|c|}{.200} & \multicolumn{3}{|c|}{.328} \\
\hline 調整済みR2乗 & \multicolumn{3}{|c|}{.084} & \multicolumn{3}{|c|}{.133} & \multicolumn{3}{|c|}{.007} & \multicolumn{3}{|c|}{.025} & \multicolumn{3}{|c|}{.095} \\
\hline
\end{tabular}

* $\beta$ : 標準化係数（ $\beta$ 係数）、 $\mathrm{t} ： \mathrm{t}$ 值、有：有意確率 *被説明変数の定義

被説明変数(1)：直接投資による新しい物流センターの建設、

被説明変数(2)：既存の物流センターへ情報システムを導入、

被説明変数(3)：外部の物流企業に委託する、

被説明変数(4)：他の卸売業者との共同出資で物流センターを建設、

被説明変数(5)：全体の売上高に占める物流システム関連の投資額の最近 3 年間のおおよその割合 
Q1. 規模

〈貴社の従業員数をご記入ください〉

合計

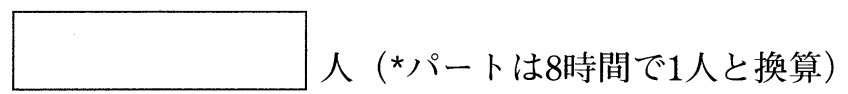

Q2. 大手小売企業への依存度

〈貴社の販売先別の売上高構成はどのようになっていますか。合計が100\%となるようにご記入ください〉
1. 百貨店（）\%
7. 一般小売店 ( )\%
2. 全国スーパーチェーン（）\%
8. 生協・農協（）\%
3. 県内スーパーチェーン ()$\%$
9. 業務用需要者 (産業使用者) $） \%$
4. コンビニエンスストア $\quad ） \%$
10. 他の卸売業（）\%
5. 量販専門店・ディスカウントストア（）\%
11. 直営小売店（）\%
6. 専門店チェーン $\quad) \%$
12. その他(
$\%$

Q3. 物流高度化 ${ }^{12}$

〈貴社は現在物流高度化を持っていますか〉
1. 直接投資をし、新しい物流センターの建設
1. 有り
2. なし
2. 既存の物流センターへ情報システムを導入
1. 有り
2. なし
3. 外部の物流企業に委託する。
1. 有り
2. なし
4. 他の卸売業者との共同出資で物流センターを建設
1. 有り
2. なし

\section{Q4. 物流投資額}

〈貴社の物流関連の投資額が、売上高全体に占める割合はどのくらいですか。最近3年間のおおよその割 合について、該当する番号 1 つに○印を打付けてください〉
1. $0 \%$
2. $5 \%$ 未満
3. $5 \sim 10 \%$ 未満
4. 10 20\%未満
5. $20 \sim 30 \%$ 未満
6. $30 \sim 50 \%$ 未満
7. $50 \%$ 以上

Q5. 物流高度化の要因

〈貴社が物流投資を行う理由として次のことをどれくらい重視していますか〉

$$
\text { まったく重視しないどちらとも言えないとても重要に思う }
$$

1. 販売先からの要求

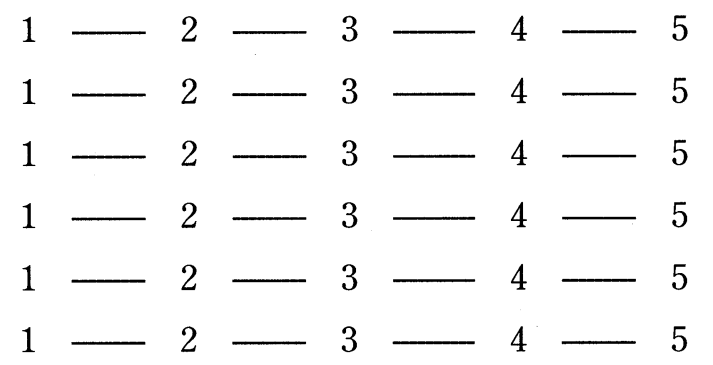




\section{謝辞}

本稿の作成にあたり、神戸大学大学院経営学 研究科教授 高嶋克義先生、『流通研究』のア リア・エディターおよびレビュアーの先生 方、現代卸売業研究会およびIOR研究会のメ ンバーの方々から貴重なコメントをいただき ました。記して感謝いたします。

\section{〈注〉}

1 本稿では流通短縮化に関する既存研究を二つで 区分しているが、それを完全に分離できるもの ではないことに注意したい。例えば、技術発達 を流通短縮化の主要因とする研究での流通サー ビス費用のシフトは、メーカーと小売企業の戦 略的行動が反映された結果として再解釈するこ ともできる。すなわち、本稿での既存研究の区 分は説明のために便宜的に設定したものであ る。

2 食料 - 飲料、医薬品 - 化粧品、機械器具、化学 製品、鉱物・金属材料の分野で資本的、かつ、 人的交流関係を伴う垂直的統合が起こらないに も関わらず、流通短縮化が行われることについ ては今後更なる検討が必要になる。

3 この議論は、本文で紹介する「卸売企業の戦略 的行動が自立的であること」と、「卸売の集中度 の変化が流通短縮化をもたらすこと」を前提と しているために、本文ではこれらに関しても記 述することにしたい。特に、前者に関しては確 認的分析が行われる。

4 大規模小売企業に対する供給業者の対応が取引 依存関係に影響を与える局面に関しては、 Galbraith(1957)の「対抗力理論」が参考になる。 また、この理論を背景理論として日本の流通を 分析した実証研究として田村 (1986)、桑原 (1989)がある。

5 ここで卸売企業が実行する「物流高度化」の自立 性を確認する理由をもう少し説明しておきた い。物流高度化に対する小売側の要求が高まる
中で、卸売企業がこれをビジネスチャンスとし て捉え、多額の物流高度化投資を積極的に行う ことは戦略的ともいえる。しかし、この視角は 戦略という概念を一般的(広義)に解釈すること になり、小売側の要求がどれほど反映されてい るかが分からない。そこで卸売企業の物流高度 化の自立性を確認することは卸売企業の戦略性 をより明確にすることになる。この卸売企業の 物流高度化の自立性確認に関しては、参考 1 で 詳しく記述される。

6 この例としては、食品卸売企業、「菱食」の物流 戦略が参考になる。菱食はRDCの導入など新物 流政策を展開する際に販売先に対して効率性を 考慮し、大規模小売企業に対しては物流機能を 担当することに専念しながらも、中堅規模の小 売企業とは戦略的提携を結び、さらに、零細規 模小売企業に対しては取引をやめる戦略を展開 した(金2001)。

7 ここで言う二極化とは、業界内の市場集中度の 変化を意味する。つまり、二極化とは上位の市 場シェアーを占有している企業の市場シェアー が拡大する現象である。大規模小売企業や大規 模卸売企業の出現と成長は、市場集中度が変化 することになるが、大規模卸売企業の物流シス テムの導入はその特徵上、大規模小売企業との 取引を拡大するように働きかける可能性が高 く、この局面では二極化は加速されることが予 想される。

8 多店舗展開戦略を主要戦略とする大規模小売企 業の場合、物流部門を供給業者に依存したほう が効率的になる局面に関しては前で記述した。 それに対応して卸売企業が物流高度化を実行す ることになると、!主要販売先との関係、”物 流システムの効率的運営、といった二つの理由 から広域展開することが必要になると考えられ る。この点に関しては、金(2004)が詳しい。

9 調査主体は『現代卸売業研究会』であり、本稿は そのデータを用いている。 
10 詳しい質問項目に関しては、参考 $2 を$ 参照のこ と。

11 卸売企業の物流高度化の自立性を確認するため に、5つの被説明変数を想定し、重回帰分析を 行った。被説明变数(1)と(2)は直接投資による物 流高度化を、被説明変数(3)と(4)は間接投資によ る物流高度化を意味する。また、被説明変数(5) は物流高度化のための投資額を測定している。 ここで、被説明変数(1)と(2)は積極的物流高度化 になり、(3)と(4)は消極的物流高度化として捉え ることが出来る。

上の結果は、すべての被説明変数に対して説明 変数(1)と(2)に因果関係が確認されなかったこと や、積極的な物流高度化を意味する被説明変数 (1)，(2)の場合、効率性向上と物流高度化との間 に因果関係が確認されたことから、全体的に、 物流高度化の要因として取引先の要求よりは卸 売企業自らの自立性による局面が大きいことが 確認された。

12 本稿では卸売企業が実行する物流高度化を卸売 企業の直接投資によるものと、間接投資による ものの二つで分けて捉えた上、その実態を確認 するために質問調查を実施した。しかし、この 趣旨とは反して卸売企業が「直接によって新し い物流センターを建設した」としても、それが 「旧式」のものだとすれば物流高度化とは言い難 いし、また卸売企業が「既存の物流センターへ 情報システムを導入した」としても、その情報 システムが物流処理能力の向上に直接関係しな いもの(例えば人員管理のための情報システム) だとすれば、これもまた「物流高度化」とはいい 難いために、分析結果に対しては慎重な解釈が 必要と思われる。

\section{〈参考文献〉}

Abell, Derek F. (1980), Defining the Business, Prentice-Hall.(石井淳蔵1984『事業の定義』)

Ansoff H.I. (1965), Corporate Strategy, McGraw-
Hill.

Bucklin, L.P. (1966) A Theory of Distribution Channel Structure, University of California.(田村正紀 訳『流通経路構造論』千倉書房、1977).

Bucklin, L. P. (1970) "National Income Accounting and Distributive Trade Cost", The Journal of Marketing, April, pp.14-22.

Bucklin, L.P. (1972) Competion and Evolution in the Distributive Trades, Prentice- Hall.

Galbraith, J. K. (1957) American Capitalism : The Concept of Countervailing Power, Revised ed., London: Hamish Hamilton.

Hall, M (1948), Distribute Trading : An Economic Analysis, Huchinson （片岡一郎訳, 『商業の経 済理論』、東洋経斉新報社 1957 .

Maltz,A. (1993) "Outsourcing the Warehousing Function : Economic and Strategic Considerations, " Logistics and Transportation Review, Vol.30,No.3,PP.245-265.

Revzan. David A. (1961) Wholesaling in marketing organization. University of California.

Revzan. David A. (1965) A Sectional View of History of Marketing in the U.S., in Marketing and Economic Development, ed. by P. D. Bennet, American Marketing Association.

Stalk,George, Philip Evans, and Lawrence E. Schulman (1992), "Competing on Capabilities : The New Rules of Corporate Strategy," Harvard Business Review, March-April.

Stern, L. W. and A. I. El - Ansary (1977), Marketing Channels, Prentice - Hall, Inc.

石井淳蔵 (1983)『流通におけるパワーと対立』千倉 書房。

今村達生 (1978)「戦後わが国卸売流通における变化

(1)」『修道商学】第19巻第2号, pp.1-20。

今村達生 (1981)「わが国卸売商業における流通迂 回率について」『修道商学』第21巻第3号, pp.149172 。 
上原征彦 (1990)「流通の将来展望」『Japan Marketing Journal $₫ 35$ 号pp4-12。

上原征彦 (1993)「流通革命論と第二次流通革命論」

『季間マーケティングジャーナル』第13巻第3号。

江上 哲 (1996)『現代流通のマクロ分析』ミネル ヴァ書房。

江尻 弘 (1980)「わが国の流通経路は本当に長いか （上、下）」『消費と流通』第4巻第3号、pp.60-70、 第4巻第4号、pp.72-79。

加藤 司 (1995)「日本的流通システムの構造変化」 『経営研究』第46巻1号, pp.37-66。

金雲鎬 (2001)「消費拠点型流通を目指している食 品卸売企業 (株) 菱食のケース研究」『神戸ビジネ スースクール・ケースシリーズ』2001年9号, pp.1-23。

金雲鎬 (2003)「卸売業者の延期化の発生メカニズ ム」『神戸大学大学院経営学研究科、モノグラフ シリーズ』第0304号, pp.1-20。

金雲鎬 (2004)「卸売業者の革新と戦略対応」『神戸 大学大学院経営学研究科、モノグラフシリーズ』 第0405号, pp.1-18。

桑原秀史(1989)『小売市場の経済分析』千倉書房。 倉沢資成 (1991)「流通の多段階性と返品制」『日本の 流通』東京大学出版会、pp.189-223。 小西一彦 $(2000)$ 「卸売業の構造変化の特質」『マーケ ティングへの歴史的視角』同文舘。

黄 りん (1997)「卸売企業の経営業績と成長戦略」 『卸売企業の経営と戦略』同文舘,pp.11-32。

榊原健郎 (1991)「卸売チャネル政策の展望」JAPAN MARKETING JOURNAL 4 1. pp 36-49。

佐藤芳彰・高宮城朝則 (1995)「卸売業の経営基盤と 戦略展開」日本商業学会誌。

住谷 宏 (1992)「高集中度販路におけるチャネル戦 略」JAPAN MARKETING JOURNAL43, pp. 223233 。

高嶋克義 (1994)『マーケティング・チャネル組織 論』千倉書房。

高嶋克義 (1998)『生産財の取引戦略』千倉書房。
高嶋克義 (2002)『現代商業学』有斐閣。

高宮城朝則 編著 (1997)『卸売企業の経営と戦略』 同文舘。

田島義博 (1962)『日本の流通革命』日本能率協会。

田島義博 - 宮下正房 編著 (1986)『日本的卸売経営 の未来』東洋経済新聞社。

田島義博・宮下正房 (1985)『流通の国際比較』有斐 閣。

田村正紀 (1973)「流通システム論の課題」『マーケ ティング理論の現状と課題』京都ワークショッ プ、白桃書房, pp.45-67。

田村正紀 (1984)「流通システム論」『日本流通研究の 展望』。

田村正紀 (1986)『日本型流通システム』千倉書房。 田村正紀 (1989)『現代の市場戦略』白桃書房。

田村正紀 (2001)『流通原理』千倉書房。

鳥居昭夫 (1983)「日本の卸売迂回度 (1)」『城西経済 学会誌』第19巻第1号, pp.105-118。

鳥居昭夫 (1987)「卸売迂回度と流通系列化」『城西経 済学会誌』第22巻第3号, pp.73-82。

中西正雄・杉本宏幸 (2002)「卸売企業によるリテー ル・サポートとその意義」『流通研究』第5巻第2 号、pp.17-34。

成生達彦 (1994)『流通の経済理論』名古屋大学出版 会。

西村清彦・坪内浩 (1990)「日本の流通は消費者に とって効率的か? 』『経済学論集』第56巻第2号, pp.43-59。

西村清彦・坪内浩 (1991)「日本の流通マージン：マ クロ分析』『日本の流通』東京大学出版会、pp.3162 。

林 周二 (1962)『流通革命論』中央公論社。

風呂 勉 (1972)「流通迂回分析の課題」『商大論集』 第24巻第4号, pp.23-43。

丸山雅祥 (1988)『流通の経済分析 : 情報と取引』創 文社。

丸山雅祥 (1992)『日本市場の競争構造』創文社。

矢作敏行 - 小川孔輔 - 吉田健二 (1993)『生・販統合 
マーケティング・システム』白桃書房。

矢作敏行 (1996)『現代流通』有斐閣。

宮下正房 (1996)『現代の流通戦略』中央経済社。

渡辺達郎 (1997)『流通チャネル関係の動態分析』千

倉書房。

渡辺達郎 (2002)「新問屋無用論と卸売業』『ベーシッ

ク流通と商業』有斐閣。

\section{〈参考資料〉}

株式会社菱食の発足20周年記念社内論文 (2000.1)。

日本食糧新聞社発行『日本の食品問屋全調査1998-

$2002 \rrbracket 。$

日経流通新聞「第30回日本の卸売業調査」(2001.8.2)。 